Key Words:

B-25

Subsidence

Retention:

Permanent

\title{
STRUCTURAL ANALYSIS FOR SUBSIDENCE OF STACKED B-25 BOXES (U)
}

\author{
William E. Jones \\ Tsu-Te Wu \\ Mark A. Phifer
}

Savannah River Technology Center

MAY 2003

UNCLASSIFIED

DOES NOT CONTAIN

UNCLASSIFIED CONTROLLED

NUCLEAR INFORMATION

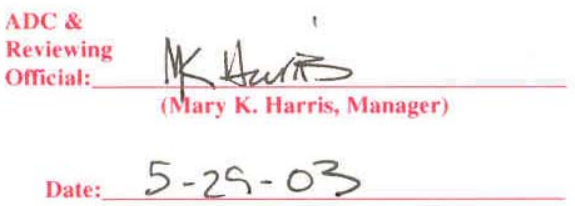

Westinghouse Savannah River Company

Savannah River Site

Aiken, SC 29808

Prepared for the U.S. Department of Energy Under

Contract Number DE-AC09-96SR18500 
This document was prepared in conjunction with work accomplished under Contract No. DE-AC09-96SR18500 with the U. S. Department of Energy.

\section{DISCLAIMER}

This report was prepared as an account of work sponsored by an agency of the United States Government. Neither the United States Government nor any agency thereof, nor any of their employees, makes any warranty, express or implied, or assumes any legal liability or responsibility for the accuracy, completeness, or usefulness of any information, apparatus, product or process disclosed, or represents that its use would not infringe privately owned rights. Reference herein to any specific commercial product, process or service by trade name, trademark, manufacturer, or otherwise does not necessarily constitute or imply its endorsement, recommendation, or favoring by the United States Government or any agency thereof. The views and opinions of authors expressed herein do not necessarily state or reflect those of the United States Government or any agency thereof.

This report has been reproduced directly from the best available copy.

Available for sale to the public, in paper, from: U.S. Department of Commerce, National Technical Information Service, 5285 Port Royal Road, Springfield, VA 22161, phone: (800) 553-6847, fax: (703) 605-6900

email: orders@ntis.fedworld.gov

online ordering: http://www.ntis.gov/help/index.asp

Available electronically at http://www.osti.gov/bridge

Available for a processing fee to U.S. Department of Energy and its contractors, in paper, from: U.S. Department of Energy, Office of Scientific and Technical Information, P.O. Box 62, Oak Ridge, TN 37831-0062,

phone: (865)576-8401,

fax: (865)576-5728

email: $\underline{\text { reports@ adonis.osti.gov }}$ 
Key Words:

B-25

Subsidence

Retention:

Permanent

STRUCTURAL ANALYSIS FOR SUBSIDENCE OF

STACKED B-25 BOXES (U)

\author{
William E. Jones \\ Tsu-Te Wu \\ Mark A. Phifer \\ Savannah River Technology Center
}

MAY 2003

Westinghouse Savannah River Company

Savannah River Site

Aiken, SC 29808

Prepared for the U.S. Department of Energy Under

Contract Number DE-AC09-96SR18500

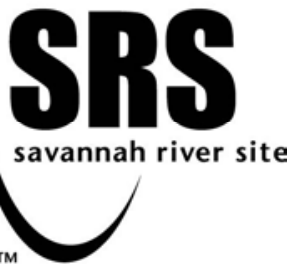


This page intentionally left blank 


\section{TABLE OF CONTENTS}

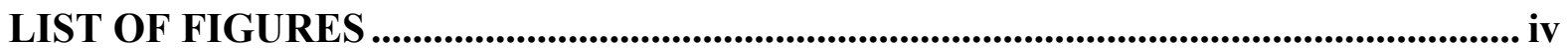

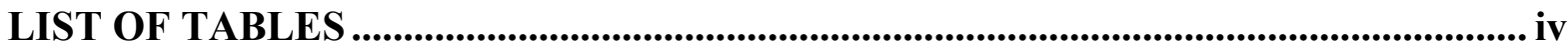

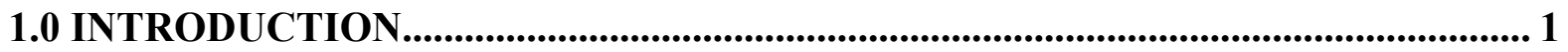

2.0 FINITE-ELEMENT STRUCTURAL ANALYSIS.......................................................... 5

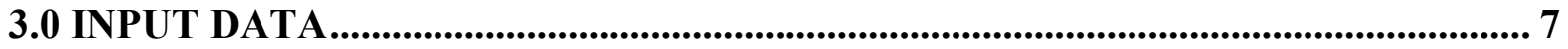

4.0 MODEL DESCRIPTION............................................................................................... 13

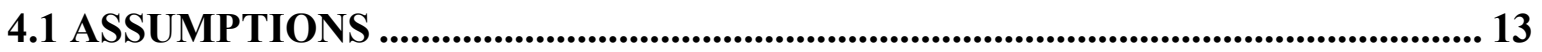

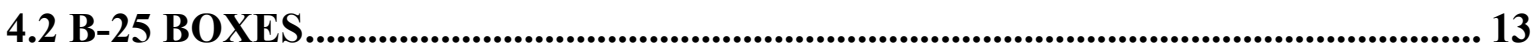

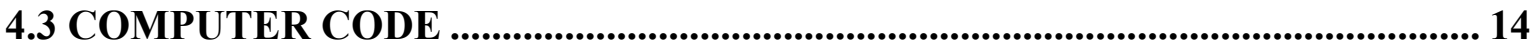

4.4 ELEMENT TYPES ……................................................................................................ 14

4.5 PRESSURE LOAD ........................................................................................................ 14

4.6 BOUNDARY CONDITIONS ..................................................................................... 15

4.7 CONTACT SURFACES ………....................................................................................... 15

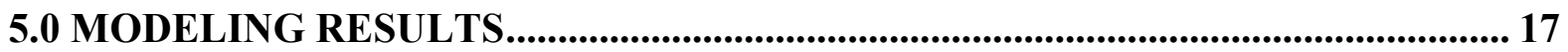

5.1 SCENARIO ONE MODELING RESULTS................................................................... 17

5.2 SCENARIO TWO MODELING RESULTS ................................................................. 17

5.3 COMPARISON OF SCENARIOS................................................................................. 17

6.0 FIELD OBSERVATIONS COMPARED TO MODELING RESULTS .................... 21

7.0 CONCLUSIONS ........................................................................................................ 25

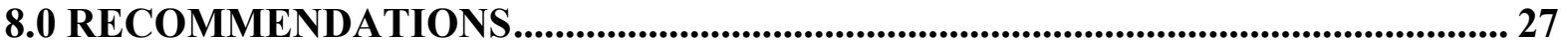

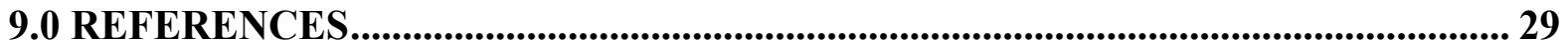




\section{LIST OF FIGURES}

Figure 1. Carbon Steel Stress-Strain Relationship (modified from Gong, 2001)................... 8

Figure 2. Pressure-Volumetric Strain Data (from HKS, 1998) ........................................... 9

Figure 3. Uniaxial Stress-Plastic Strain Data (from HKS, 1988) ........................................ 9

Figure 4. B-25 Deformation from static surcharge loading after twenty-five years beneath an interim soil cover .................................................................................. 18

Figure 5. B-25 Deformation from static surcharge loading after various years beneath an interim soil cover ........................................................................................... 19

Figure 6. Net deflection (difference from original height) of stack of four B-25s for each

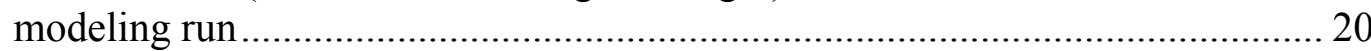

Figure 7. B-25 lid pushed 0.5 to $1.5 \mathrm{ft}$ within B- 25 container by 8 -ft-thick soil overburden. B-25 excavated in 2001 (Dunn, 2002).

Figure 8. B-25 excavated in 2001 turned on its side to remove soil overlying the deformed B-25 lid (Dunn, 2002) ................................................................................. 23

Figure 9. Bottom of deformed lid from B-25 excavated in 2001 (Dunn, 2002) .................. 23

Figure 10. Lid deflection for scenario one cases - static surcharge after 25 years burial..... 24

\section{LIST OF TABLES}

Table 1. Low-Level Waste Streams Placed in the Engineered Trench.................................... 3

Table 2. Pressure-Volumetric Strain Data (from HKS, 1998) ............................................ 10

Table 3. Uniaxial Stress-Plastic Strain Data (from HKS, 1988)......................................... 10

Table 4. Scenario One Modeling Input: Lid, Bottom, and Sides Thickness at 25Years Since Disposal for the Three Steel-Volume Loss Methods........................................... 11

Table 5. Scenario Two Modeling Input: Lid, Bottom, and Sides Thickness at Later Years for the Three Steel-Volume Loss Methods......................................................... 11

Table 6. Exterior Dimensions of B-25 Box .................................................................... 14 
WSRC-TR-2002-00378

\subsection{INTRODU CTION}

The Savannah River Site (SRS) and other U.S. Department of Energy (DOE) sites use shallow land burial facilities (i.e., trenches) to dispose low-level radioactive waste. DOE Order 435.1, Radioactive Waste Management, and its companion manual and guide require that certain Performance Objectives be met over a 1,000-year period after closure in order to protect the public, environment, and workers. The requirement to achieve long-term stability, minimize waste material/container subsidence, and minimize the need for long-term active maintenance for long-term cover systems is one such requirement.

However, at SRS and other DOE sites, waste containers with up to 90 percent void space are disposed in the shallow land burial facilities. Corrosion and degradation of these containers can result in significant subsidence over time, which can compromise the integrity of the long-term cover. This in turn can lead to increased water infiltration through the long-term cover into the waste and subsequent increased radionuclide transport into the environment. Understanding and predicting shallow-buried, low-level waste subsidence behavior is necessary for evaluating cost-effective and appropriate stabilization required to maintain cover system long-term stability and viability, and to obtain stakeholder acceptance of the long-term implications of waste disposal practices.

Two methods (dynamic compaction and static surcharge) have been used at SRS to accelerate waste and container consolidation and reduce potential subsidence prior to longterm cover construction. Dynamic compaction comprises repeatedly dropping a heavy (20 ton) weight from about a $40-\mathrm{ft}$ height to consolidate the waste and containers. Static surcharge is the use of a thick ( $15 \mathrm{ft}$ to $30 \mathrm{ft}$ ) soil cover to consolidate the underlying materials over a longer time period (three to six months in this case).

The DOE Subsurface Contaminants Focus Area funded a project that uses SRS Engineered Trench \#1 (ET) as a case study for evaluating low-level radioactive waste subsidence. The ET is a large, approximately 20 -foot-deep trench into which metal boxes (B-25 boxes) containing low-level radioactive waste are stacked four high. Previous work on this project has produced several published reports. Jones and $\mathrm{Li}$ (2001) summarizes ET geotechnical and design information, waste container, climate, and seismic information pertinent to subsidence modeling. Dynamic compaction behavior of B-25 containers using finite element modeling is described in two previous reports, Gong (2001) and Gong and Jones (2002). Dunn (2002) presents a corrosion evaluation for a B-25 container excavated near the ET, including corrosion rates, types, and their locations on the B-25. Development of three methods for calculating B-25 lid, bottom, and side steel volume loss through time due to corrosion for the ET is presented in Jones and Phifer (2002).

Quasi-static modeling of a stack of four B-25 boxes at various stags of corrosion with an applied static surcharge has been conducted and is presented herein. The scenario modeled is static surcharge, where a soil cover 25 -ft-thick is applied over an interim soil cover 6-ft-thick (plus bulldozer weight) to yield a total 3,986.63 psf load. 
The approach focuses on B-25 container use for low-level waste disposal. Although several container types are being disposed in the ET, the primary container type (over 77 percent) is the B-25 (Phifer and Wilhite, 2001). Modeling this type container only is both reasonable and necessary due to time and computer limitations for modeling. The steel volume loss for each part of the B-25 is converted to reduced thickness for finite element modeling use. The three methods are termed the Constant Volume Method, the Continuous Incipient Area Method (most rapid thickness reduction), and the Slowing Corrosion Method (least rapid thickness reduction, reflecting corrosion slowing with time). The modeling presents a general indication of the subsidence behavior that might be expected.

Inherent uncertainty, including the following items, makes it clear that the modeling is not to be regarded as a strict indicator of subsidence that should be expected over the entire ET.

- the containers' physical state at burial (some containers exhibit large areas of corrosion prior to burial, while others appear pristine)

- the variation in waste volume (ranging from about 10 percent to 90 percent void space)

- type of waste contained (from cloth to steel)

- stiffness and mechanical strength of the waste

- the variety of containers

- the uncertainty of projecting corrosion rates based on a single datum (one B-25 excavated at one point in time rather than a number of B-25s evaluated at various burial times)

\section{B-25 Containers}

The inside dimensions of B-25 containers are $1.83 \mathrm{~m}$. long, $1.17 \mathrm{~m}$ wide, and $1.19 \mathrm{~m}$ high ( $6 \mathrm{ft}$ long, $3.83 \mathrm{ft}$ wide and $3.9 \mathrm{ft}$ high). The outside dimensions are $1.85 \mathrm{~m}$ long, $1.19 \mathrm{~m}$ wide and $1.32 \mathrm{~m}$ high (6.078 ft long, $3.911 \mathrm{ft}$ wide and $4.323 \mathrm{ft}$ high), including the risers along the container bottom. The B-25 interior is $2.55 \mathrm{~m}^{3}\left(90 \mathrm{ft}^{3}\right)$. The containers are constructed of 12-gauge low-carbon steel. The interior is primed. The exterior is primed and painted. Additional details are available in Phifer and Wilhite (2001) and Jones and Li (2001).

\section{Waste Characteristics}

The ET will contain low-level radioactive waste (LLW). LLW is radioactive waste that is not classified as high-level waste, transuranic waste, spent fuel, or by-product material as defined in DOE Order 435.1, and does not contain Resource Conservation and Recovery Act-regulated hazardous waste (Jones and $\mathrm{Li}, 2001$ ). It consists of radioactively contaminated materials, such as miscellaneous job control waste, small equipment, plastic sheeting, gloves, wood, debris, and soil. 
SRS has 13 LLW streams (treatability groups) in a wide range of physical forms. LLW from nine of these streams may be placed in the ET (Table 1). Although several container types are being disposed in the ET, modeling has been limited to the most common configuration a four-high stack of B-25 containers.

Table 1. Low-Level Waste Streams Placed in the Engineered Trench

No Treatment Low-Level Bulk Waste

Low-Level Waste Direct to Compactor

Low Activity Bulk Waste

Bulk Metal to Direct Disposal

Incinerable Low Activity Liquid Waste

Bulk Metal to Survey/

Decontamination

Contaminated Large Equipment to Survey/Decontamination

Contaminated Large Equipment to Size Reduction

TRU Waste Less than $100 \mathrm{nCi} / \mathrm{g}$ Alpha-Contaminated (Non-Mixed) Drums
Boxed waste from Naval Reactor Facilities and onsite generators, packaged for direct disposal

Low-Level Alpha Waste, compactable waste packaged in drums for compaction by generators, and projected waste (FY06) from the Tritium Extraction Facility

Legacy waste stored in B-25s and newly generated Low Activity Waste

Facility 232-F legacy equipment and future job control waste, scrap, and components

Oil, oil and water, or water, with some chemical waste may go to the ET after treatment

Newly generated scrap and components which have been segregated at the generator for survey and decontamination

Material or components that are too large for disposal in a standard container, including pumps, jumpers, scaffolding, trailers, process equipment, etc.

Material or components such as reactor process water heat exchangers that are too large to fit in a standard waste container

Alpha-contaminated LLW currently classified as transuranic (TRU) waste packaged in drums (Jones and Li, 2001) 


\section{Engineered Trench \#1 Description}

The ET is located in E Area at SRS. Its first phase has a capacity of approximately $9,100 \mathrm{~m}^{3}$, with additional sections to be constructed as required. Currently, the first phase has been filled with B-25s and other low-level radioactive waste containers, and the second phase is in use. The ET is sized to allow stacking B-25s four high. Although containers placed in the first phase included B-12s, 55-gallon drums, and other containers, the most common configuration is B-25s stacked four high.

The ET excavation is by standard heavy-construction equipment (e.g., backhoe and dump truck). The bottom of the ET is approximately 17 to $20 \mathrm{ft}(6 \mathrm{~m})$ below ground surface. First phase trench-bottom dimensions are approximately $150 \mathrm{ft}(45 \mathrm{~m})$ wide by $210 \mathrm{ft}(64 \mathrm{~m})$ long, at an elevation of $261 \mathrm{ft}(79.55 \mathrm{~m}) \mathrm{msl}$. First phase ground surface dimensions are approximately $200 \mathrm{ft}(61 \mathrm{~m})$ wide by $260 \mathrm{ft}(79 \mathrm{~m})$ wide, at a typical ground-surface elevation of $280 \mathrm{ft}(84.8 \mathrm{~m}) \mathrm{msl}$.

The ET bottom is constructed with a geotextile filter underlying a granite gravel layer approximately 6 in. $(0.15 \mathrm{~m})$ thick. The trench bottom is compacted using a minimum of five passes of a vibratory roller having a dynamic force of 30,000 lbs per drum.

When the construction phase of the ET is filled with B-25s and other containers, the containers are covered with a minimum 4-ft $(1.2 \mathrm{~m})$ soil thickness, consolidated by the bulldozer pushing soil over the container tops. The ET design allows extending the next trench section while operation continues in the previous section. A roadway leading into the ET is about $30 \mathrm{ft}(9.1 \mathrm{~m})$ wide, with a five-percent grade. A flatbed truck, forklift, or crane may be used for disposing B-25s. A 35-ft-minimum (10.6-m-minimum) interior turning radius for heavy equipment is allowed on the ET base.

The base is sloped to move water runoff to a low-point sump for collection and pumping (using a portable pump on an elevated surface). The ET bottom is constructed with a sump to collect any runoff for analysis prior to disposal. Sump-top dimensions are approximately $30 \mathrm{ft}(9.1 \mathrm{~m}) \times 40 \mathrm{ft}(12.2 \mathrm{~m})$. The sump is designed to accommodate rainfall from a 6-hour 25 -year storm event for one-third of the ET area. The ET floor is used to accommodate the difference between the design storm event (24-hour 500-year return period) and the 6-hour 25-year storm event. Water depth within the ET will not be allowed to exceed $2 \mathrm{ft}(0.61 \mathrm{~m})$, to prevent B-25s from floating. The sump design allows the sump to be pumped out in four hours. A rigid pipe is located near the sump to move water away from the sump and direct the water, at the top of the slope, toward the existing drainage ditch. The existing performance assessment requires a minimum of $25 \mathrm{ft}(7.6 \mathrm{~m})$ of undisturbed soil between the trench floor and the underlying water table.

The ET walls are sloped to allow personnel to work safely at the trench base. Minimum sideslope is $1: 1$. The side-slope is designed with a safety factor of 1.5 against slope stability failure where site-specific strength data are not available. Erosion control features for keeping the walls intact include erosion control matting and seeding of slopes. Life expectancy of the entire trench is at least 20 years. 
WSRC-TR-2002-00378

\subsection{FINITE-E LEMENT STRUCTURAL ANALYSIS}

Finite-element analyses have been performed to determine the structural deformation of the four stacked B-25 boxes subjected to the static loads of overlaying soil and to evaluate the effect of corrosion on the deformation. Two scenarios of static loads (Jones and Phifer, 2002) are considered. Scenario One is to apply the load after the containers have been in the ground for about 25 years. Scenario Two is to apply the load after the containers have been buried for a longer period of time. For both scenarios, the effect of steel-volume loss due to corrosion over time is accounted for, based on estimates from the three different methods presented in Jones and Phifer (2002).

Although the boxes are subjected to a static load, the structural responses of the boxes vary with time. (The analytical results indeed show that the deflection, buckling and post buckling of the components of the stacked boxes occur in sequence rather than simultaneously.) Therefore, it is more appropriate to treat the problems considered as quasistatic rather than static; namely, the structural response of the stacked boxes are dynamic transient with very long duration. Furthermore, the finite-element model has complex contact and slide conditions between the interfaces of the contacting components, its numerical solution is more tractable by using explicit time integration schemes.

The finite-element model was previously developed by Gong (2001) using the ABAQUS computer code, with the finite element mesh generated by MSC/PATRAN graphic software for dynamic compaction analysis. The current model presented herein has been modified from that previously developed. The modifications and their rationale are summarized as follows.

1. Since the lid of the uppermost box of the four stacked B-25 boxes is expected to deflect and slide before the box starts to buckle or collapse, the lid cannot be considered as an integral part of the box body. The lids of all four boxes are remodeled as separate pieces, and contact and slide conditions between the lids and box rims are added.

2. The meshes of the soil base and the infinite elements are modified to eliminate the contact and slide conditions between the bottom surface of the lowermost box and the upper surface of the soil base. It is believed that the excessive deformation speed (approaches the sonic speed) that terminated the computation prematurely as reported by Gong (2001) occurred on the contact surfaces between the bottom surface of the lowest box and the upper surface of the soil base. This kind of phenomenon normally occurs with a contact pair where one contact surface is much stiffer than the other contact surface. Since, in reality, the top surface of the soil base will move with the bottom surface of the lowermost box, the finite-elements of the riser bottom surfaces and the soil base in the contact area can shear the nodes. 
3. The original model uses a bi-linear stress-strain curve for the low-carbon steel material of the B-25 boxes. A more realistic stress-strain curve is generated based on the same values of yield stress, ultimate strength and uniform elongation as given in Gong (2001). 


\subsection{INPUT DA TA}

The geometrical configurations of the B-25 boxes are given in Gong (2001). The stressstrain curve used in the Gong (2001) compaction analysis is bi-linear, having two straight lines (one line for linear elastic material behavior and a second line for material behavior after initial yield). A stress-strain curve thought to more closely reflect steel deformation behavior has been generated using the parameters from Gong (2001). This curve is presented in Figure 1 and used for the current modeling.

The material properties of soil underlying the B-25s used in the present analysis are changed from those given in Gong (2001). The soil/B-25 contact has been made a rigid contact (to simplify modeling while producing realistic results).

The contents of the B-25 boxes are low-level radioactive wastes, loosely disposed in the box with void ratio ranging from $10 \%$ to $90 \%$. The equivalent mechanical properties of the waste are not available and highly variable. In the present analysis, the material properties of the contents are represented by published values (HKS, 1998) of a crushable foam as presented in Figure 2 and Figure 3. Values for these curves are presented in Table 2 and Table 3, respectively. This curve differs from the two curves presented in Gong (2001) that were based on mechanical properties of Celotex ${ }^{\mathrm{TM}}$, a man-made material manufactured from sugarcane fibers. The end result is that the waste material modeled here is stronger than that previously modeled.

Other waste material properties used in the current modeling include:

- $\quad$ Density $=305 \mathrm{~kg} / \mathrm{m} 3$

- Young's Modulus $=0.129 \mathrm{GPa}$

- Poisson's Ratio $=0$ 


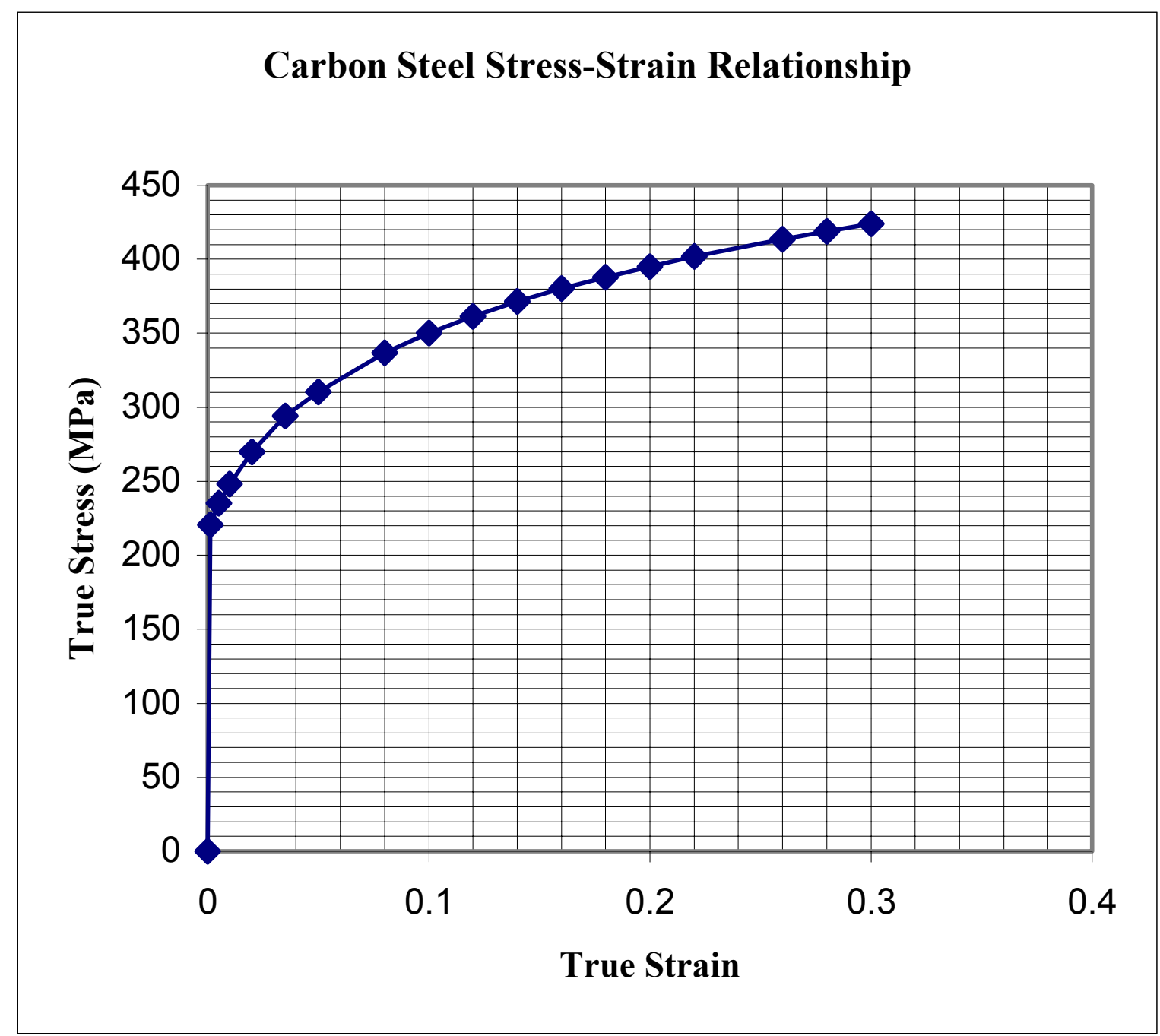

Figure 1. Carbon Steel Stress-Strain Relationship (modified from Gong, 2001) 


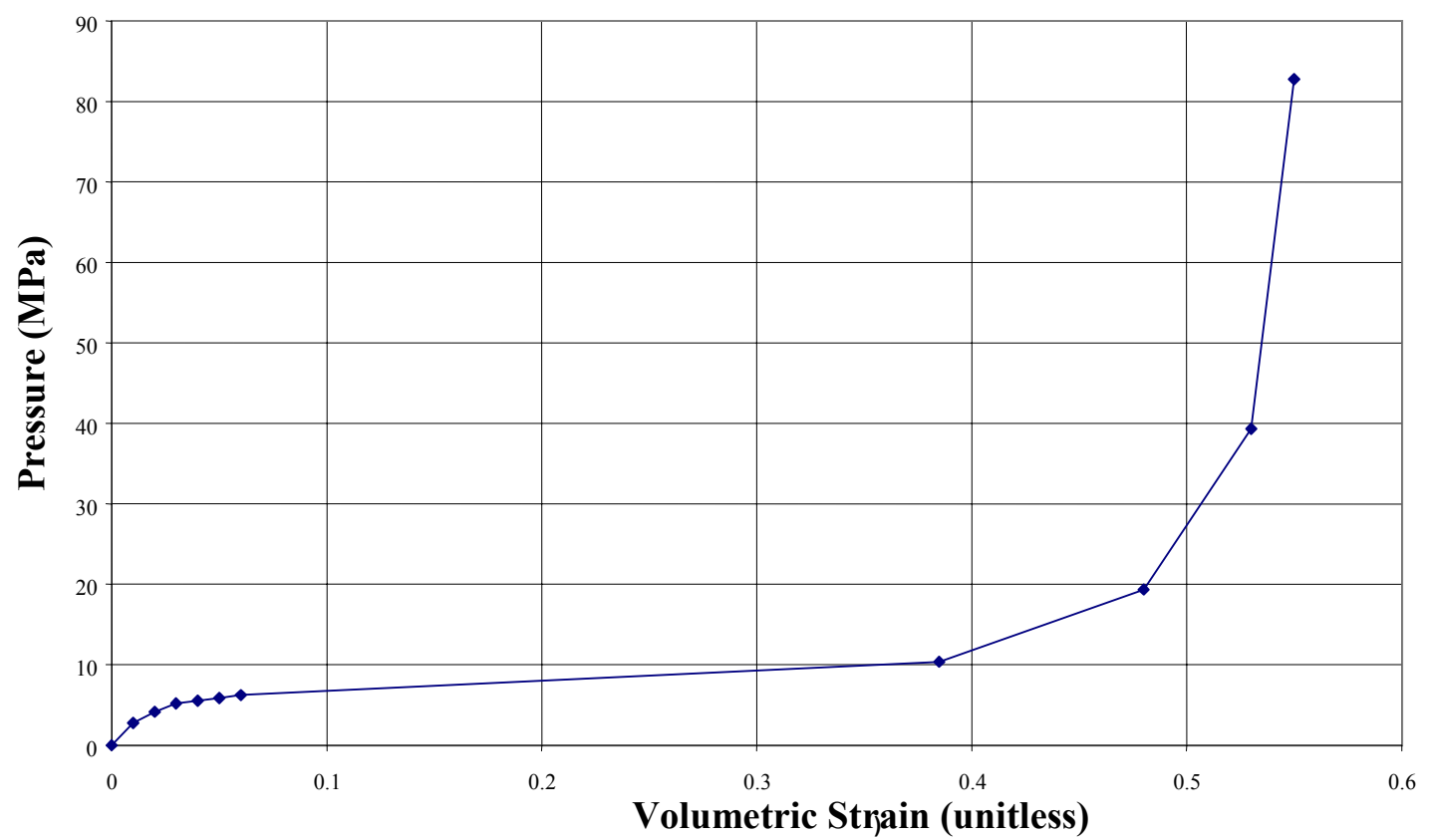

Figure 2. Pressure-Volumetric Strain Data (from HKS, 1998)

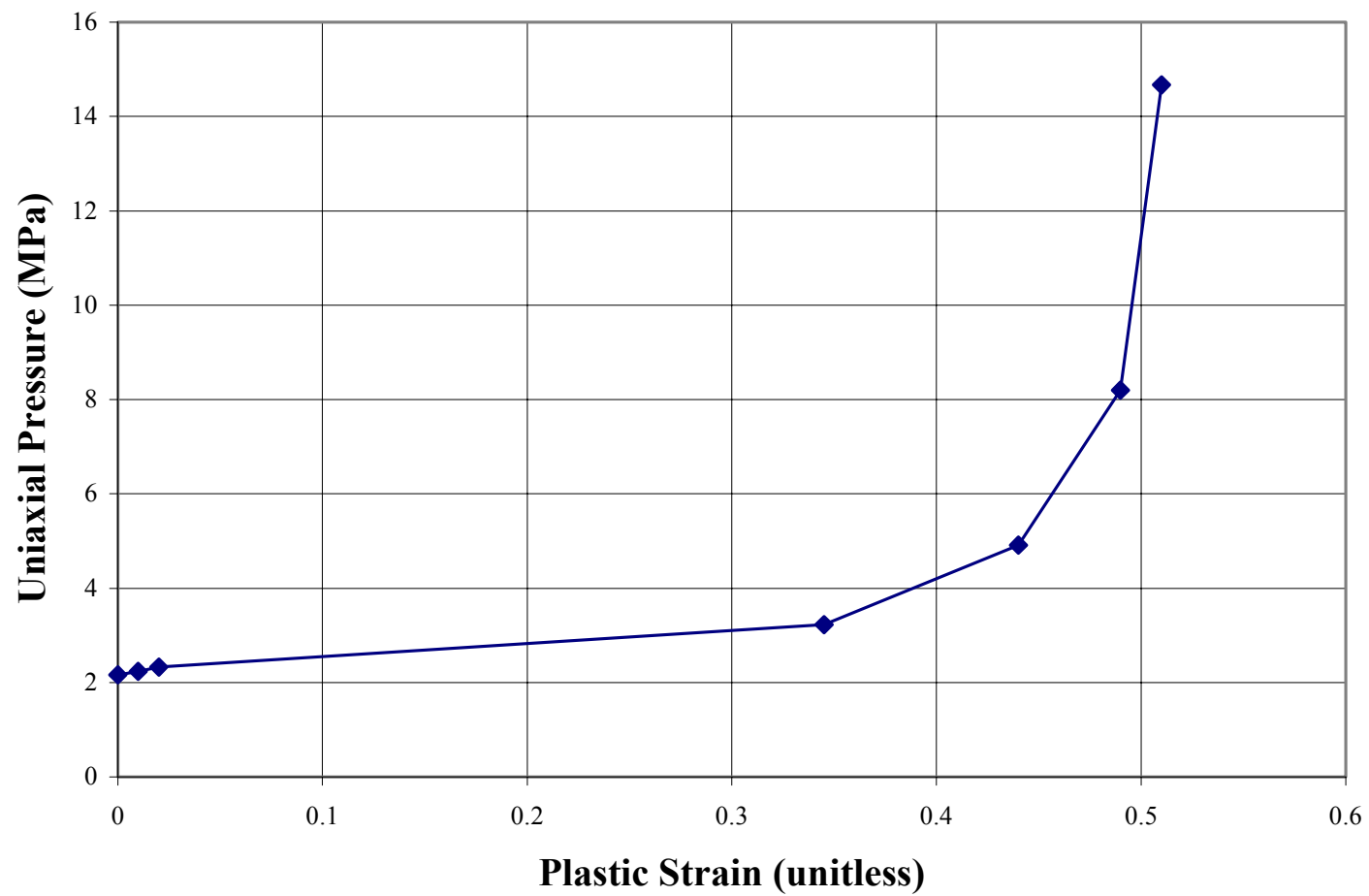

Figure 3. Uniaxial Stress-Plastic Strain Data (from HKS, 1988) 
Table 2. Pressure-Volumetric Strain Data (from HKS, 1998)

\begin{tabular}{|c|c|}
\hline $\begin{array}{c}\text { Volumetric Strain } \\
\text { (unitless) }\end{array}$ & $\begin{array}{c}\text { Pressure } \\
\text { MPa }\end{array}$ \\
\hline 0 & 0 \\
\hline 0.01 & 2.76 \\
\hline 0.02 & 4.14 \\
\hline 0.03 & 5.17 \\
\hline 0.04 & 5.52 \\
\hline 0.05 & 5.86 \\
\hline 0.06 & 6.21 \\
\hline 0.385 & 10.34 \\
\hline 0.48 & 19.31 \\
\hline 0.53 & 39.3 \\
\hline 0.55 & 82.74 \\
\hline
\end{tabular}

Table 3. Uniaxial Stress-Plastic Strain Data (from HKS, 1988)

\begin{tabular}{|c|c|}
\hline $\begin{array}{c}\text { Volumetric Strain } \\
\text { (unitless) }\end{array}$ & $\begin{array}{c}\text { Pressure } \\
\text { MPa }\end{array}$ \\
\hline 0 & 2.16 \\
\hline 0.01 & 2.24 \\
\hline 0.02 & 2.33 \\
\hline 0.345 & 3.23 \\
\hline 0.44 & 4.91 \\
\hline 0.49 & 8.2 \\
\hline 0.51 & 14.67 \\
\hline
\end{tabular}

The pressure loads applied on the lid of the uppermost box for both scenarios are equal to

The sum of the weight of a 25 -ft-thick static surcharge load of soil

PLUS the weight of a 6-ft-thick interim soil cover load

PLUS the heavy equipment (bulldozer) weight

EQUALS Total Weight $=3,986.63 \mathrm{lb} / \mathrm{ft}^{2}$ (Jones and Phifer, 2002)

Thus, the pressure load applied on the top surface of the lid of the uppermost box is:

$$
P=3,986.63 \mathrm{lb} / \mathrm{ft}^{2}=190,882.059 \mathrm{~Pa}\left(\mathrm{~N} / \mathrm{m}^{2}\right)
$$


B-25 steel-thickness properties for modeling are presented in Jones and Phifer (2002).

Scenario One models the behavior of a stack of four B-25s under static surcharge, 25 years after placement of an interim 6-ft-thick soil cover. The total load includes both the interim soil cover and the static surcharge soil. Thicknesses of the B-25 lid, bottom, and sides for the Constant Volume, Continuous Incipient Area, and Slowing Corrosion Methods at 25 years are provided in Table 4.

Table 4. Scenario One Modeling Input: Lid, Bottom, and Sides Thickness at 25Years Since Disposal for the Three Steel-Volume Loss Methods

\begin{tabular}{|l|c|c|c|c|c|c|c|}
\hline \multicolumn{1}{|c|}{$\begin{array}{c}\text { Steel } \\
\text { Volume-Loss } \\
\text { Method }\end{array}$} & $\begin{array}{l}\text { Years } \\
\text { Since } \\
\text { Disposal }\end{array}$ & $\begin{array}{c}\text { Lid } \\
\text { Percent } \\
\text { Loss }\end{array}$ & $\begin{array}{c}\text { Lid } \\
\text { Thickness } \\
\text { (in.) }\end{array}$ & $\begin{array}{c}\text { Bottom } \\
\text { Percent } \\
\text { Loss }\end{array}$ & $\begin{array}{c}\text { Bottom } \\
\text { Thickness } \\
\text { (in.) }\end{array}$ & $\begin{array}{c}\text { Sides } \\
\text { Percent } \\
\text { Loss }\end{array}$ & $\begin{array}{c}\text { Sides } \\
\text { Thickness } \\
\text { (in.) }\end{array}$ \\
\hline $\begin{array}{l}\text { Constant Volume } \\
\text { Method }\end{array}$ & 25 & 8.9 & 0.0996 & 25 & 0.0821 & 5.95 & 0.1029 \\
\hline $\begin{array}{l}\text { Continuous } \\
\text { Incipient } \\
\text { Corrosion Method }\end{array}$ & 25 & 23.3 & 0.0839 & 25.2 & 0.0818 & 15.9 & 0.0920 \\
\hline $\begin{array}{l}\text { Slowing Corrosion } \\
\text { Method }\end{array}$ & 25 & 3.9 & 0.1051 & 10.9 & 0.0974 & 2.7 & 0.1064 \\
\hline
\end{tabular}

Scenario Two models the behavior of a stack of four B-25s under static surcharge at later years $(150,68$, and 250 years since disposal for the Constant Volume, Continuous Incipient Area, and Slowing Corrosion Methods, respectively). Again, the total load includes both the interim soil cover and the static surcharge soil. These years were selected because they approach the time at which either the lid, bottom, or sides would suffer 100 percent corrosion or zero thickness. Thicknesses for these B-25 ages are presented in Table 5.

Table 5. Scenario Two Modeling Input: Lid, Bottom, and Sides Thickness at Later Years for the Three Steel-Volume Loss Methods

\begin{tabular}{|l|c|c|c|c|c|c|c|}
\hline \multicolumn{1}{|c|}{$\begin{array}{c}\text { Steel } \\
\text { Volume-Loss } \\
\text { Method }\end{array}$} & $\begin{array}{l}\text { Years } \\
\text { Since } \\
\text { Disposal }\end{array}$ & $\begin{array}{c}\text { Lid } \\
\text { Percent } \\
\text { Loss }\end{array}$ & $\begin{array}{c}\text { Lid } \\
\text { Thickness } \\
\text { (in.) }\end{array}$ & $\begin{array}{c}\text { Bottom } \\
\text { Percent } \\
\text { Loss }\end{array}$ & $\begin{array}{c}\text { Bottom } \\
\text { Thickness } \\
\text { (in.) }\end{array}$ & $\begin{array}{c}\text { Sides } \\
\text { Percent } \\
\text { Loss }\end{array}$ & $\begin{array}{c}\text { Sides } \\
\text { Thickness } \\
\text { (in.) }\end{array}$ \\
\hline $\begin{array}{l}\text { Constant Volume } \\
\text { Method }\end{array}$ & 150 & 49 & 0.0558 & 89 & 0.0120 & 36 & 0.0700 \\
\hline $\begin{array}{l}\text { Continuous } \\
\text { Incipient } \\
\text { Corrosion Method }\end{array}$ & 68 & 79.3 & 0.0226 & 53.8 & 0.0505 & 57.6 & 0.0464 \\
\hline $\begin{array}{l}\text { Slowing Corrosion } \\
\text { Method }\end{array}$ & 250 & 29 & 0.0777 & 77 & 0.0252 & 20 & 0.0875 \\
\hline
\end{tabular}


This page intentionally left blank.

Page 12 of 30 


\subsection{MODEL DESCRIPTION}

\subsection{ASSUMPTIONS}

The following assumptions were made to keep the analysis tractable:

1. The overlaying soil is not modeled. The weight of soil over the lid of the uppermost box is treated as the distributed pressure load.

2. Although the accumulation of the overlaying soil is a slow process, the equivalent pressure load is applied onto the lid of the uppermost box within 5 milliseconds (0.005 seconds).

3. The soil on which the stack of boxes rests is densely packed so the soil can be represented by a rigid surface.

\subsection{B-25 BOXES}

The lid and the side wall of the uppermost B-25 box are separate components so the interfaces of these two components undergo complicated contacting/separating conditions while the lid is being deformed and then pushed into the inside of the box by the soil weight. This scenario is described in the following paragraphs.

The inner surface of the lid and the top edges and the outer surface of the walls are initially in contact. After the equivalent pressure load of the soil weight is applied onto the top surface of the lid, the center portion of the lid starts to deflect into the void inside the box. When the lid deflects further, the four edges of the lid will be bent outward and the walls of the box are no longer able to prevent the lateral motion of the lid edges. At this stage either the inner surface or the edge of the lid is in contact with the top edges of the box walls. Eventually the entire lid may be pushed into the inside of the box. When this happens, either the edges or inside surface of the lid will be in contact with the inside surface of box.

The implicit numerical scheme cannot simulate the complicated interface-contacting conditions described above. Therefore, the explicit numerical scheme is being used for the present analysis. Furthermore, the explicit numerical scheme involves the propagation of stress waves in the model, and thus the subsidence study of the stacked B-25 boxes must be treated as a dynamic problem, although the loading is static. Since the response of structure to the loading is very slow, the problem is categorized as "quasi-static." A quasi-static problem is usually more difficult to analyze than the high-speed, dynamic problem because of the long computing time, unless the mass scaling technique can be applied to increase the size of stable-time step by reducing the speed of the sonic waves travelling in the model. However, the structural response in the present analysis is due to a direct external load; thus increasing the densities of the model components will not only increase the size of the stabletime step, but also reduce the velocities of the components. In other words, mass scaling is not effective to the present problem. 
The exterior dimensions of the B-25 box used in the modeling are presented in Table 6 .

Table 6. Exterior Dimensions of B-25 Box

\begin{tabular}{|l|l|}
\hline Exterior Dimensions & Length (m) \\
\hline Length & 1.84 \\
\hline Width & 1.18 \\
\hline Height (excluding riser) & 1.2 \\
\hline Riser Height & 0.1 \\
\hline Thickness (12 gauge) & 0.00265684 \\
\hline
\end{tabular}

\subsection{COMPUTER CODE}

The ABAQUS/Explicit Computer Code, version 5.8 (HKS, 1998) has been used to perform the computations. The finite-element meshes were generated using the MSC/PATRAN computer program.

\subsection{ELEMENT TYPES}

The components of the B-25 box, including the lid, walls, bottom plate, and the riser, are all comprised of 3D shell elements (Type S4R elements in the ABAQUS Computer Code). The waste content is represented by $3 \mathrm{D}$ brick elements (Type C3D8R). The soil foundation is modeled by using a total of six layers of 3D brick elements (Type C3D8R), plus a bottom layer of infinite element (Type CIN3D8R).

\subsection{PRESSURE LOAD}

The pressure loads applied on the lid of the uppermost box for both scenarios are equal to the sum of the weight of a 25 -ft-thick static surcharge load of soil, plus the weight of a 6 -ft-thick interim soil cover load, plus the weight of a bulldozer - total weight 3,986063 lb/ $\mathrm{ft}^{2}$. Thus, the pressure load applied on the top surface of the lid of the uppermost box is:

$$
P=3,986.63 \mathrm{lb} / \mathrm{ft}^{2}=190,882.059 \mathrm{~Pa}\left(\mathrm{~N} / \mathrm{m}^{2}\right)
$$

The amplitude of the pressure load applied to the lid of the uppermost box varies with time according to a smooth function. As a result, the response of the box structure to the pressure load varies smoothly with time.

The downward gravitational load acting at the boxes and waste contents is equal to $32.20 \mathrm{ft} / \mathrm{sec}^{2}\left(9.815 \mathrm{~m} / \mathrm{sec}^{2}\right)$. 


\subsection{BOUNDARY CONDITIONS}

The reference nodes of the rigid elements that represent the soil foundation are fixed. Thus, all three translations in the horizontal $\mathrm{x}$ and $\mathrm{y}$ directions and vertical $\mathrm{z}$ direction are equal to zero, and the rotations about the $\mathrm{s}, \mathrm{y}$, and $\mathrm{z}$ axes are also equal to zero.

$$
\mathrm{UX}=\mathrm{UY}=\mathrm{UZ}=\mathrm{RX}=\mathrm{RY}=\mathrm{RZ}=0
$$

\subsection{CONTACT SURFACES}

The contact conditions on the interfaces of the model components are simulated using the contact surfaces and the contact pair options as well as the penalty method available in the ABAQUS Code. 
This page intentionally left blank.

Page 16 of 30 


\subsection{MODELIN G RESULTS}

\subsection{SCENARIO ONE MODELING RESULTS}

Figure 4 presents the model results for the Constant Volume, Continuous Incipient Area, and Slowing Corrosion Methods, respectively, after static surcharge following 25 years burial under an interim soil cover. The red containers represent the original undeformed B-25 condition. The black, crushed-appearance containers represent the B-25s after the load has been applied. As expected after such a short number of years since burial, the results show similar amounts of B-25 displacement, since relatively little difference exists in lid, bottom, and wall thickness among the three methods.

\subsection{SCENARIO TWO MODELING RESULTS}

Figure 5 presents the model results for:

- Constant Volume Method after static surcharge following burial under an interim soil cover for 150 years

- Continuous Incipient Area Method after static surcharge following burial under an interim soil cover for 68 years

- Slowing Corrosion Method after 250 years under an interim soil cover.

Differences are obvious in B-25 displacement, especially between the Continuous Incipient Area Method at only 68 years and the Slowing Corrosion Method at 250 years.

\subsection{COMPARISON OF SCENARIOS}

The difference in B-25 displacement (difference from original height of a stack of four B-25s) for each of the six cases modeled is presented in Figure 6. The displacement (or deflection) is graphed against model-running time, not time of burial or time since surcharge added. Cases 1, 3, and 5 are the Constant Volume, Continuous Incipient Area, and Slowing Corrosion Methods, respectively, after 25 years interim cap burial. Cases 2, 4, and 6 are the same methods, respectively, after 150 years, 68 years, and 250 years, respectively. Figure 6 shows the relatively greater displacement under the Continuous Incipient Area Method compared to the other two methods. Stack height is reduced by about $2.5 \mathrm{~m}$ after 150 years under the Constant Volume Method, by about $2.7 \mathrm{~m}$ after only 68 years under the Continuous Incipient Area Method, and by about $1.9 \mathrm{~m}$ after 250 years under the Slowing Corrosion Method. 


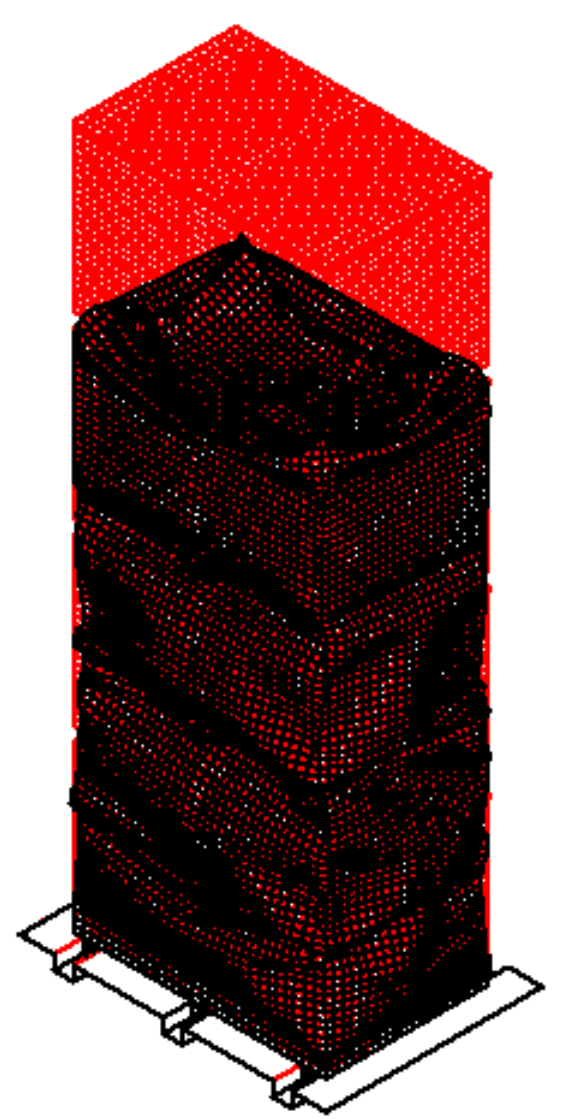

Constant Volume Method

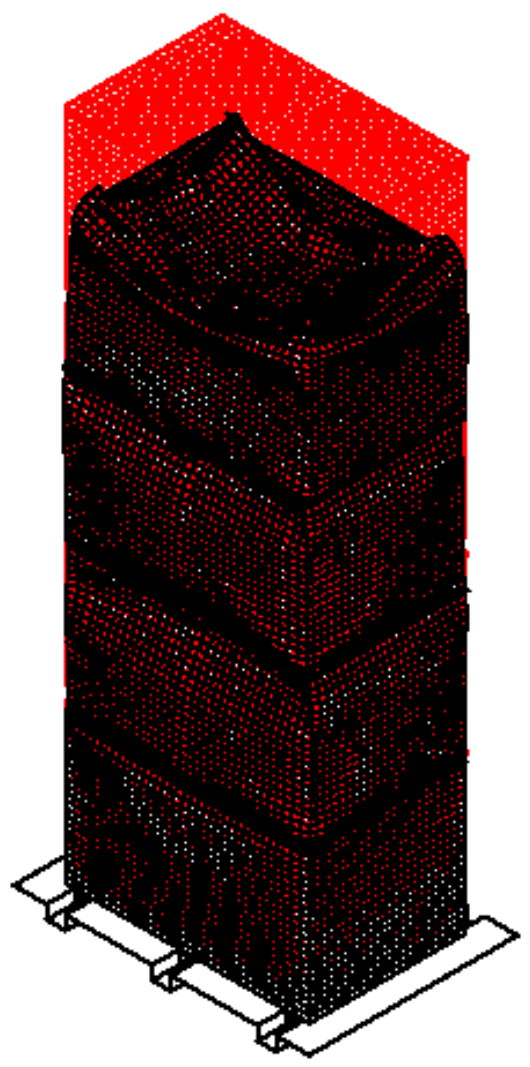

Incipient Area Method

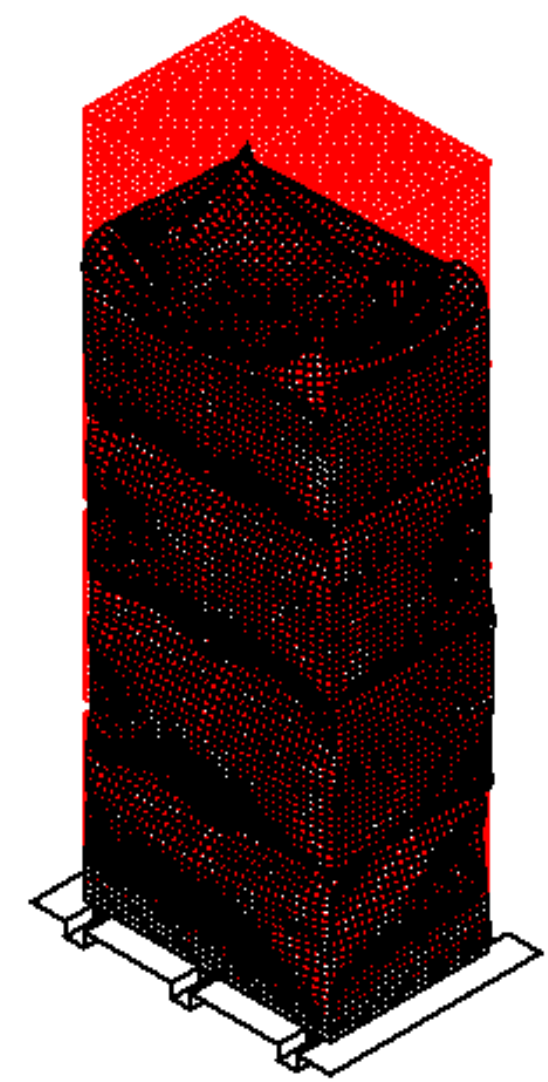

Slowing Corrosion Method

Figure 4. B-25 Deformation from static surcharge loading after twenty-five years beneath an interim soil cover 

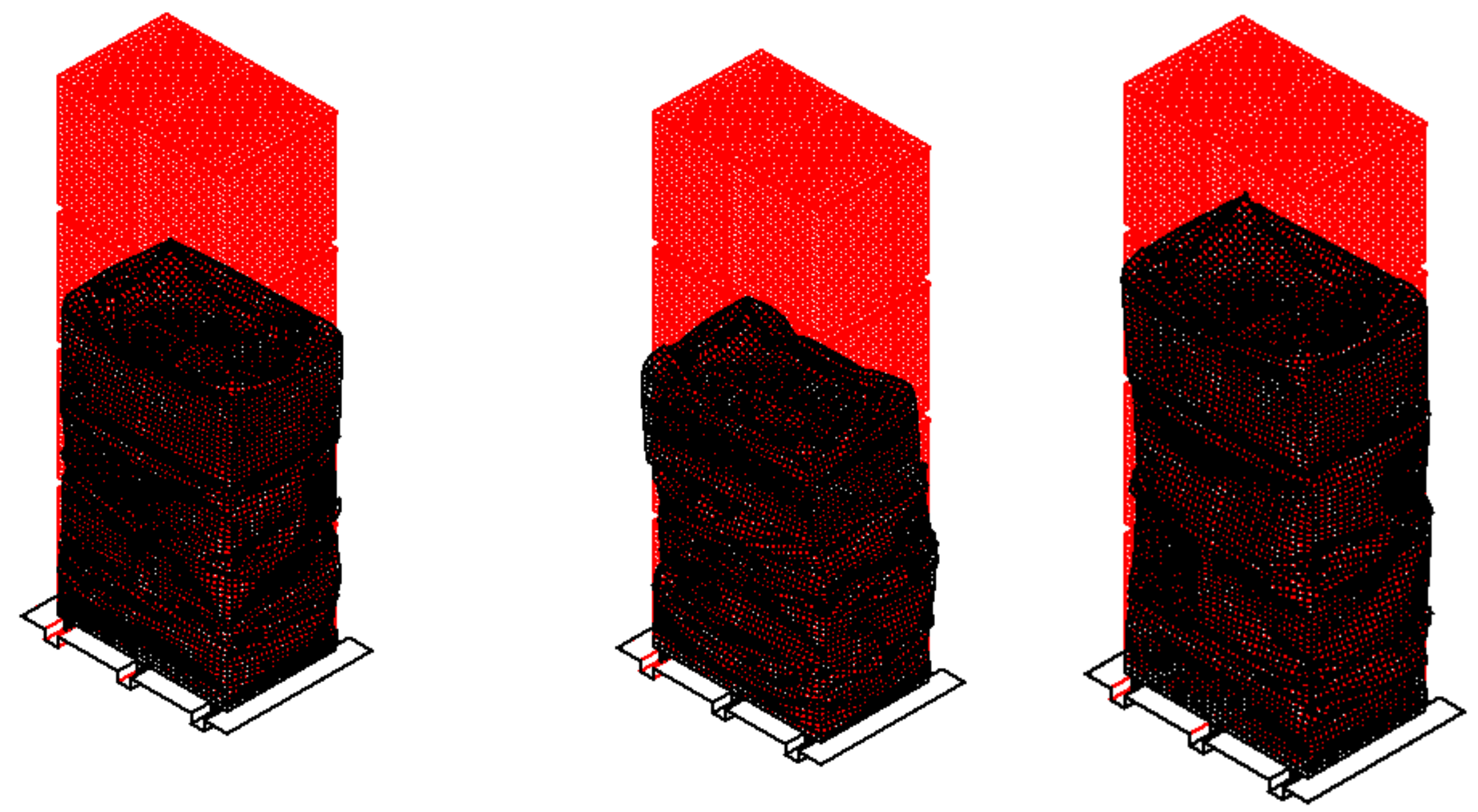

Constant Volume Method - 150 Years

Incipient Area Method - 68 Years

Slowing Corrosion Method - 250 Years

Figure 5. B-25 Deformation from static surcharge loading after various years beneath an interim soil cover 


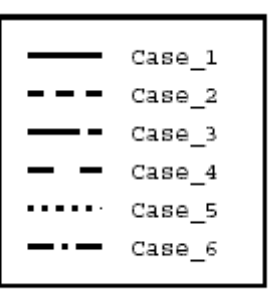

XMIN $0.000 \mathrm{E}+00$

XMAX $3.000 \mathrm{E}-0$

YMIN $-2.696 \mathrm{E}+00$

YMAX $0.000 \mathrm{E}+00$

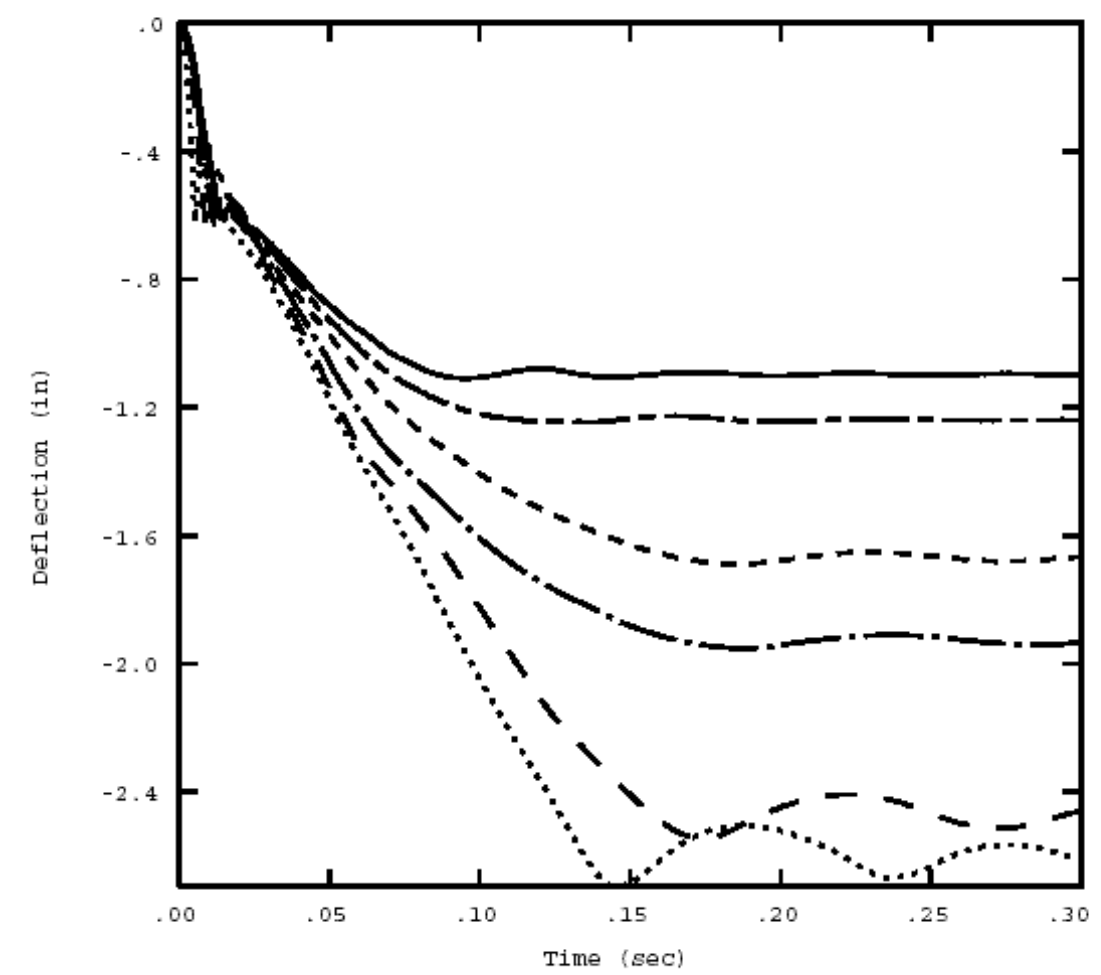

Case 1 - Constant Volume Method, static surcharge performed 25 years after initial burial

Case 2 - Continuous Incipient Area Method, static surcharge performed 25 years after initial burial

Case 3 - Slowing Corrosion Method, static surcharge performed 25 years after initial burial

Case 4 - Constant Volume Method, static surcharge performed 150 years after initial burial

Case 5 - Continuous Incipient Area Method, static surcharge performed 68 years after initial burial

Case 6 - Slowing Corrosion Method, static surcharge performed 250 years after initial burial

Time in seconds is electronic run time for model.

Figure 6. Net deflection (difference from original height) of stack of four B-25s for each modeling run 


\subsection{FIELD OBSERVATIONS COMPARED TO MODELING RESULTS}

The quasi-static modeling indicates the lid for the uppermost B-25 container will bow and be pushed down inside the container, probably by the interim soil cover weight alone. This is consistent with field observations for the B-5 excavated in 2001 (Dunn, 2002; Jones and Li, 2001) and for earlier theoretical studies (Yau, 1986; Dames and Moore, 1987). Figure 7 through Figure 9 show the buckled lid from the B-25 excavated in 2001. Figure 10 depicts the model results for the Scenario One cases' lid deflection.

Two previous studies have estimated the average total subsidence potential for a stack of four B-25 containers with typical SRS LLW. Dames and Moore (1987) estimated a total subsidence potential of $4.4 \mathrm{~m}(14.5 \mathrm{ft})$ and Phifer and Wilhite (2001) estimated a total $4.6 \mathrm{~m}$ $(15.1 \mathrm{ft})$ of subsidence potential. Within the present analysis, a subsidence of $2.7 \mathrm{~m}(8.8 \mathrm{ft})$ was the modeling result for the Continuous Incipient Area Method after 68 years. At 68 years, the Continuous Incipient Area Method produces a percent thickness loss of approximately 80 percent, 54 percent, and 58 percent, respectively, for the lid, bottom, and sides (see Figure 6).

The modeling shows significant B-25 structural integrity remains at 68 years, which prevents total elimination of the original subsidence potential. Placement of a static surcharge on the ET at 68 years results in a remaining subsidence potential of approximately 40 percent based upon the Continuous Incipient Area Method. Even more subsidence potential remains using the other corrosion scenarios. These results suggest delaying static surcharge until some period ( +68 years) after burial will result in greater consolidation than surcharge immediately after burial. 


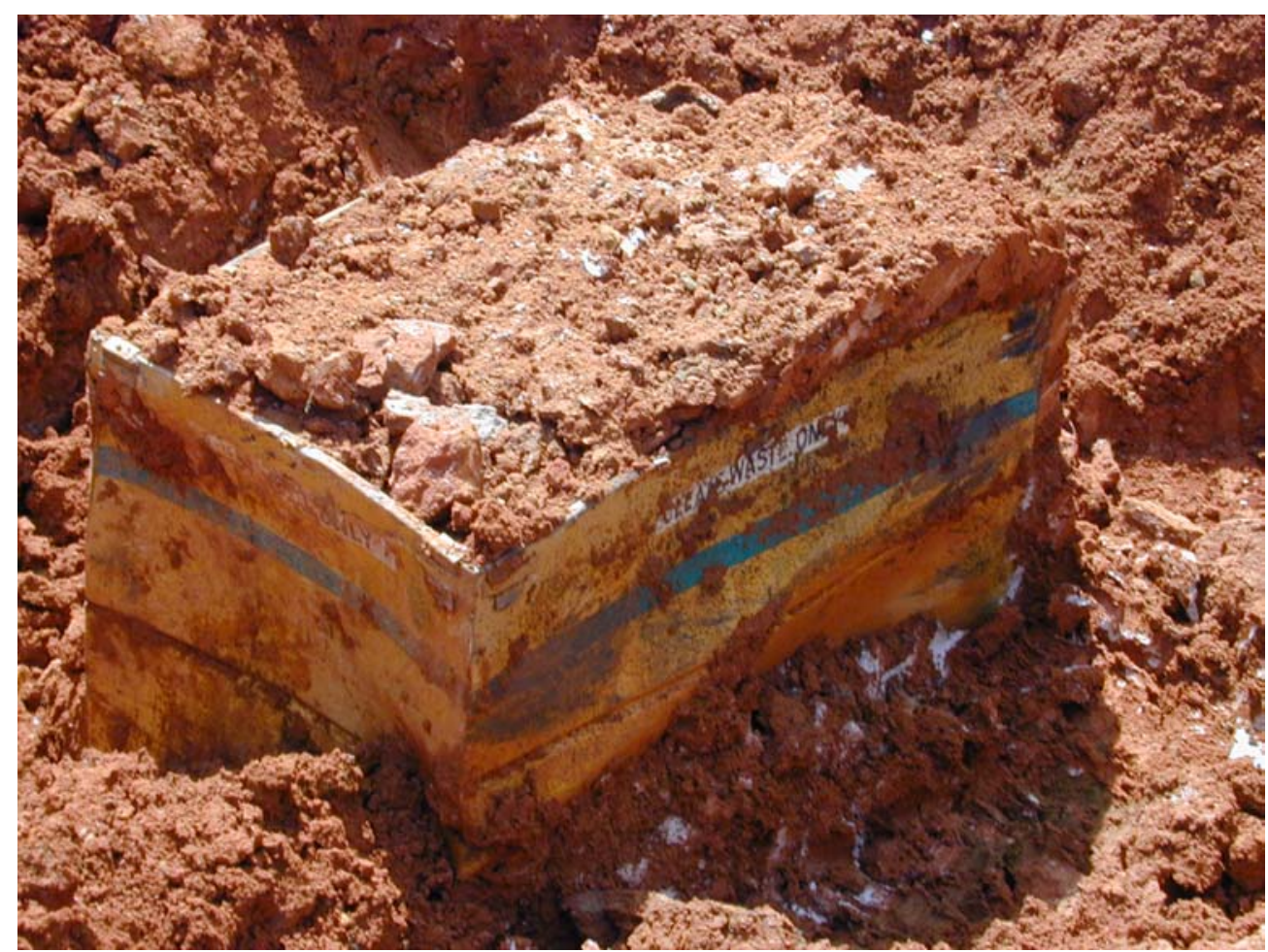

Figure 7. B-25 lid pushed 0.5 to $1.5 \mathrm{ft}$ within B-25 container by 8-ft-thick soil overburden. B-25 excavated in 2001 (Dunn, 2002). 


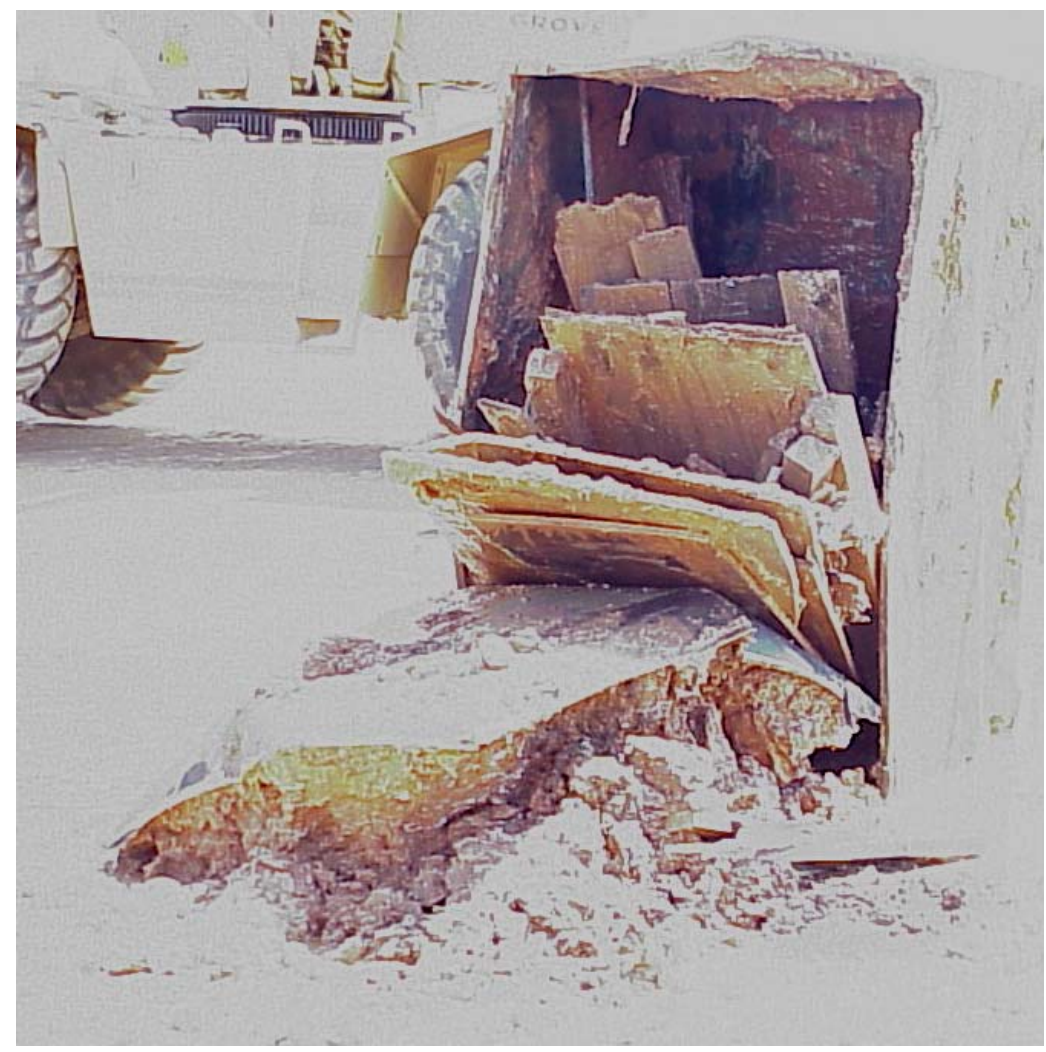

Figure 8. B-25 excavated in 2001 turned on its side to remove soil overlying the deformed B-25 lid (Dunn, 2002).

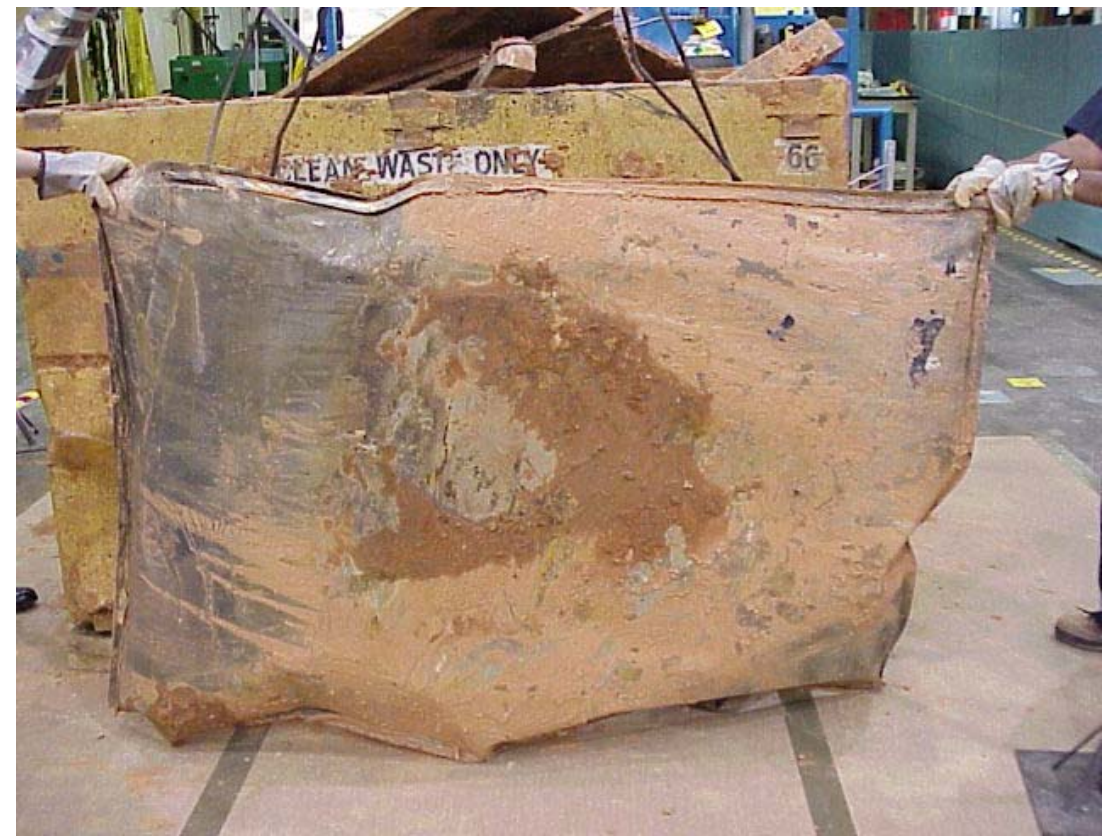

Figure 9. Bottom of deformed lid from B-25 excavated in 2001 (Dunn, 2002) 
WSRC-TR-2002-00378
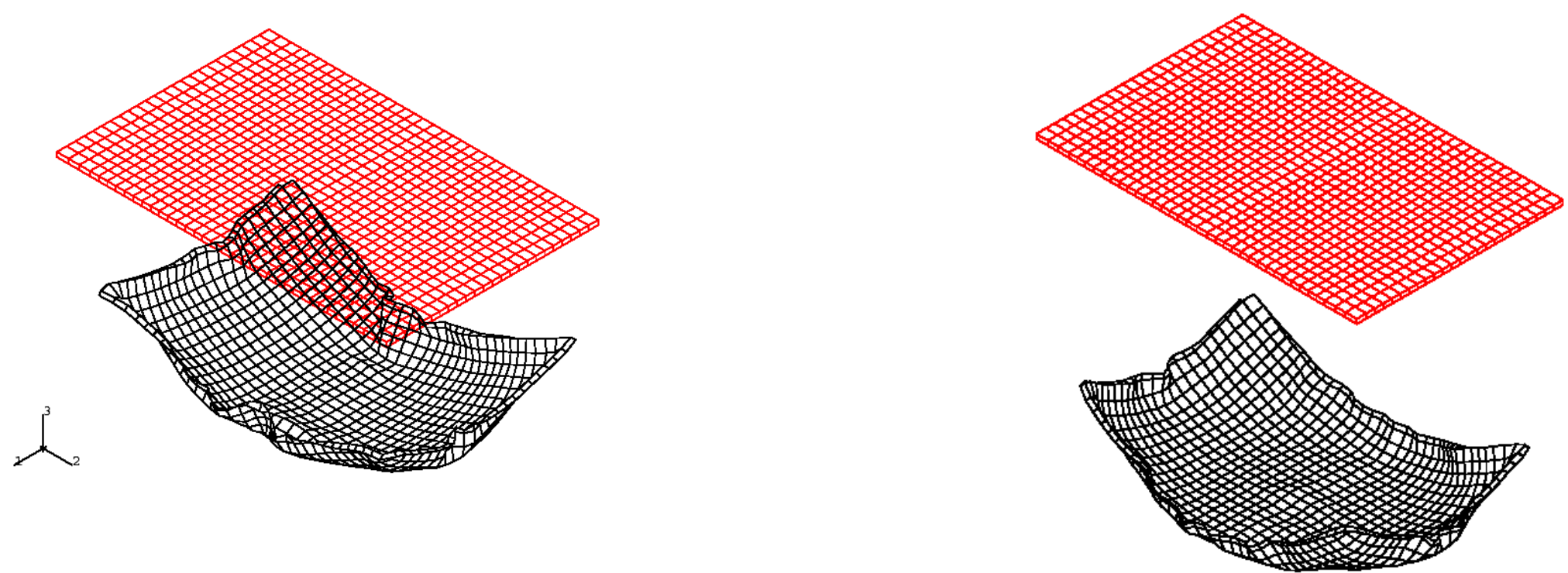

Constant Volume Method

Continuous Incipient Area Method

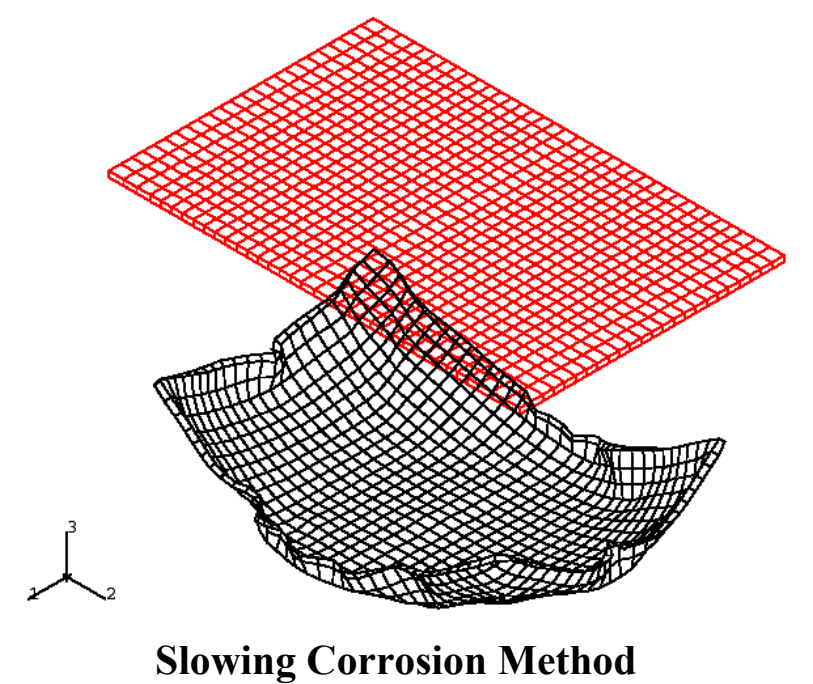

Figure 10. Lid deflection for scenario one cases - static surcharge after 25 years burial 


\subsection{CONCLUS IONS}

Quasi-static finite element modeling provides deformation results for a stack of four B-25 containers under a static surcharge load applied to three corrosion scenarios following various time lengths of initial burial under an interim soil cover. The results agree with expected differences in deformation for different degrees of corrosion. Additionally, the results demonstrate that the timing of static surcharge application relative to corrosion extent greatly impacts the degree of subsidence potential reduction that can be achieved. The same should be true with the application of dynamic compaction.

The greatest uncertainty associated with this analysis is that the corrosion scenario best representing reality is unknown. Therefore, the timing associated with the corrosion is not bounded well enough to predict when an engineering enhancement such as static surcharge will result in completely eliminating further waste subsidence.

Uncertainty is also associated with the waste's unknown mechanical properties (i.e., stiffness or mechanical strength). The mechanical values assumed for modeling purposes are thought reasonable, as supported by the reasonable modeling results. In fact, given the variability of the waste streams, the values assumed probably apply nearly perfectly to the contents of many B-25s. The assumed values may be improved if strength testing is performed. 
This page intentionally left blank. 


\subsection{RECOMMENDATIONS}

It has been demonstrated that finite element modeling is capable of reasonably representing the behavior of containerized low-level radioactive waste during long-term disposal by shallow burial. Such modeling is a useful tool for evaluating various waste consolidation options, such as dynamic compaction and static surcharge, or to evaluate subsidence without active consolidation activities.

Corrosion rates for this study are based upon a single datum, i.e., corrosion analysis of one B-25 container buried for eight years. Additional corrosion information would allow narrowing the range of corrosion rates for future subsidence modeling and evaluation of subsidence treatment options. It is recommended that corrosion and subsidence monitoring instrumentation be installed in the ET. Such instrumentation could include:

- Strain gauges

- Lysimeters to obtain water samples for analysis of $\mathrm{pH}, \mathrm{Eh}, \mathrm{DO}$, conductivity, temperature, chloride, nitrate, sulfate, iron, and iron speciation

- Atmospheric corrosion monitors, possibly both within and outside boxes to determine time of wetness

- Polarization resistance probes or typical water level tapes within boxes to determine the water level within containers

- Coated and uncoated electrodes to monitor electrical potential

- Direct electrical-potential monitoring of the B-25s themselves

- Impedence probes to measure resistance to current

- Electrochemical noise monitoring

It is also recommended that one of the remaining buried B-25s should be excavated for corrosion analysis in about 8 to 10 years. This would provide a second datum at a second burial duration for corrosion rate refinement.

Secondary to the corrosion evaluation recommendations, it is recommended that consideration be given to producing estimates of the various waste material types. Based upon these estimates, strength testing of representative samples could be performed to improve input data associated with the waste. 
This page intentionally left blank.

Page 28 of 30 


\subsection{REFEREN CES}

Dames and Moore, Inc. (1987), Subsidence Study B-25 Metal Containers Mixed Waste Management Facility, DMSRP-97, March 4, 1997, letter report Charles T. Allen to Alex Guanlao, E. I. DuPont de Nemours \& Company, Inc., Savannah River Plant, Aiken, SC 29808.

Dunn, Kerry (2002), B-25 Corrosion Evaluation Summary Report (U), WSRC-TR-200100587, January 2002, Westinghouse Savannah River Company, Aiken, SC 29808.

Gong, Chung (2001), Finite Element Analysis of Dynamic Compaction of a Stack of Four B-25 Containers (U), WSRC-TR-2001-00320, August 2001, Westinghouse Savannah River Company, Aiken, SC 29808.

Gong, Chung and Jones, William E. (2002), Finite Element Analysis Enhancement for B-25 Container Dynamic Compaction (U), WSRC-TR-2002-00353, September 2002, Westinghouse Savannah River Company, Aiken, SC 29808.

HKS (1998), ABAQUS/Explicit User's Manual Version 5.8, Hibbitt, Karlsson \& Sorensen, Inc., Pawtucket, RI 02860-4847.

Jones, William E. and Li, William (2001), Long-Term Waste Stabilization Parameter Estimation, Savannah River Site, Aiken, South Carolina (U), WSRC-TR-2001-00323, September 2001, Westinghouse Savannah River Company, Aiken, SC 29808.

Jones, William E. and Phifer, Mark A. (2002), Corrosion and Potential Subsidence Scenarios for Buried B-25 Waste Containers (U), WSRC-TR-2002-00354, September 2002, Westinghouse Savannah River Company, Aiken, SC 29808.

Phifer, Mark A. and Wilhite, Elmer L. (2001), Waste Subsidence Potential Versus Supercompaction, WSRC-RP-2001-00163, September 27, 2001, Westinghouse Savannah River Company, Aiken, SC 29808. 
This page intentionally left blank.

Page 30 of 30 